\title{
Social Interactions among Multi-Ethnic Students
}

\author{
Abdul Talib Hashim ${ }^{1}$, Noor Insyiraah Abu Bakar ${ }^{1}$, Nordin Mamat ${ }^{1} \&$ Abdul Rahim Razali ${ }^{1}$ \\ ${ }^{1}$ Faculty of Education and Human Development, Sultan Idris Education University, Malaysia \\ Correspondence: Abdul Talib Hashim, Faculty of Education and Human Development, Sultan Idris Education \\ University (UPSI), 35900 Tanjong Malim, Perak, Malaysia. Tel: 60-154-811-7476. E-mail: \\ abdul.talib@fppm.upsi.edu.my
}

Received: June 5, 2015 Accepted: November 13, 2015 Online Published: June 21, 2016

doi:10.5539/ass.v12n7p47 URL: http://dx.doi.org/10.5539/ass.v12n7p47

\begin{abstract}
Positive social interaction is a vital aspect of maintaining a harmonious condition, especially in Malaysia, a country which has a multiracial society. Therefore, this study was carried out to identify the patterns of social interactions among multiethnic students in national secondary schools in Malaysia. The respondents for this study comprise two school administrators, seven teachers and 20 students of various ethnicities. They were selected through purposive sampling. Data were collected through interview sessions either individually or in focus groups, observation and document analysis. The study's findings showed that, there are five patterns of social interaction such as cooperation, exchange, competition, conflict and non-verbal communication among multiethnic students. Although there was conflict, the underlying causes of the conflict were not due to racial issues. As well as the five patterns of social interactions stated above, stereotypes were also reported among students. Despite conflicts and stereotypes, the students actively attempted to learn about other cultures and demonstrated attitudes of acceptance towards friends from other ethnic backgrounds. This indicates that the social interaction among students is still favorable and can be further improved through appropriate response. Additionally, based on these findings, a few recommendations were made regarding this issue.
\end{abstract}

Keywords: etnic diversity, social interaction, national unity, education policy, multicultural education

\section{Introduction}

Social interaction among students is given attention by the government because it indicates the relationships within the Malaysian society in general. Malaysia is an example of a country with a multi-ethnic and multi-cultural setting in the South East Asian region (Shamsul, 1993; Nikitina \& Furuoka, 2013). Although this uniqueness is admirable, sometimes this multiplicity can cause conflicts (Lai \& Sidin, 2012). According to M.Shamsul Haque (2003) among the matters that have become issues in ethnic conflicts in Malaysia are key problems derived from political, administrative, economical, educational, language, religious and cultural aspects. In order to maintain harmony in Malaysia, freedom is given to each individual to practice various religions, customs and cultural practices without any restrictions (Tan et al., 2008).

\subsection{Multi-etnicity in Malaysia}

Multi-ethnicity in Malaysia has occurred due to changes in the Malaysian political structure; for example, during the colonization era and through other factors such as ethnic migration (Azmah, 2001). The arrival of various ethnic groups from around the world started in the $14^{\text {th }}$ century owing to commercial activities in the Melaka port (Haris, 1990; Jayum, 2003). The arrival of multiple ethic groups continued until the British occupancy, when increased numbers of Chinese and Indians came to Malaya during the early $19^{\text {th }}$ century (Hazri, 2010; Onwubiko, 2012). The main reasons for the arrival of Indians was due to the better economic conditions and political stability in Malaya compared to their own country (K. Ambalakan, 2008; Ishak, 2009), whereas, poverty and civil war had caused the Chinese to migrate to Malaya (Azmah, 2001). The arrival of both ethnic groups en masse had caused changes to the composition of the population in Malaya at that time. In addition to this, the formation of Malaysia on 16 September 1969, which involved the unification of Sabah, Sarawak and the Peninsular, had also caused an increase in the number of other ethnic groups in Malaysia (Suhana \& Jacob, 2012).

Now, the Malaysian society consists of three main ethnicities; Malays make up $50.4 \%$, Chinese $23.7 \%$, and Indians 7.1\% respectively (Source: Population and housing census of Malaysia, 2000). Besides these three main 
ethnic groups, there are other ethnic groups such as the Orang Asli (the indigenous peoples) and other ethnic groups from Sabah and Sarawak. According to Miller (2007), Sabah and Sarawak have a multi-ethnic indigenous society and each ethnic group has its own language, customs and religious practices. For example, in Sabah alone there are at least 25 ethnic groups (Ismail \& Hussin, 2009).

In Malaysian society, religion is an important part of a person's identity, coinciding with the first principle of the National Pillars (Rukun Negara). Although Article 3(1) of the Federal Constitution states that the religion of the federation is Islam, the practice of other religions can be practiced without any hindrance. Berns et al (2005) stated that, although Islam is the official religion, each ethnic group is given the liberty to practice their own religion and hold their own beliefs. This is a very important step towards ensuring that peace among the various ethnic groups can be maintained.

\subsection{Ethnic Diversity and the National Education System}

The primary school education system has been carried out through different medium of instructions as a result of the needs of the various ethnicities. Simply put, schools have been influenced as a result of the education system left after the British occupancy era (Yasmin \& Najeemah, 2010). Education based on varying medium utilizes the mother tongue of the chosen ethnicity, as the language used during the learning and teaching sessions (Sufean, 2004). Usually these schools have a homogenous student base. Thus, interaction among different ethnic groups will not take place if the student is in a mono-ethnic school surrounding (Yip, Seaton \& Sellers, 2010; Lee, Howes \& Chamberlain, 2007). Besides that, different medium school separate ethnic groups, and this can impede upon their interactions (McKenzie \& Purdy, 2010). It can be concluded, if this separation continues in the education system (Pettigrew, Wagner \& Christ, 2010) it would have an effect on social interactions (O'Nions, 2010) or cause polarization among different ethnic groups (Santhiram \& Tan, 2010).

The education policy during the British era was discriminatory, limited and caused ethnic disunity (Haris, 1990; Suseela \& Nagappan, 2012). It had been the British policy to allow each ethnic group to maintain their own identity, for example through a different schooling system, so that the ethnic groups would not be united and threaten British authority (Yasmin \& Najeemah, 2010). So, after independence the importance in improving the education system in order to achieve this unity was realized by all parties.

From this realization emerged initiatives such as the Barnes Report (1950), the Fenn-Wu Report (1951) and the Education Ordinance (1952); but the Razak Report (1956) was the foundation for the forming of ethnic unity through education (Suseela \& Nagappan, 2012). This initiative has been continued until today.

The education system practiced today is based on the National Education Policy (NEP). The NEP was formulated based on the Razak Report (1956), Education Ordinance (1957), Rahman Talib Report (1960), Education Act (1961), Cabinet Committee (1974) and was intended to form unity among ethnic groups starting from the school level, through a uniformity of the education system (Jayum, 2003; Mohd Amar, Hazri \& Najeemah, 2013). The uniformity in education can be seen through the focus on the language mode, curriculum and learning syllabus, and these aspects are paramount in sustaining unity (Mohd Sohaimi, Dayu \& Budi, 2011). After 57 years of independence, a number of changes can be seen in the education system. However, the unity agenda is still a priority in our education (Amir, 2006).

Education plays an important role in building good ethnic relations and is an important key in achieving unity (Zvi, Ayala \& Nader, 2011; Yan, Timothy \& Yiu, 2011). It is therefore vital that the education system functions as a platform for students to interact so that mutual understanding and tolerance may be achieved (Santhiram \& Tan, 2010; Gomes \& Holmberg, 2010; Özgen \& Köşker, 2015).

\subsection{Social Interactios between Multi-etnic Students and Its Theoritical Perspective}

If we intend to maintain unity among ethnic groups, interaction needs to start when the individual is in his or her schooling days. Usually the school is the first place where individuals from various cultural backgrounds, will meet and play, a role which exposes the student to socialization (Vedder \& O'Dowd, 1999; Mior Khairul Azrin, 2011; Sarafidou, Govaris \& Loumakou, 2013). Based on the functional theory, since the school is the first place where students meet, the students need to play their role in accordance with the demands of their school and society, socializing and cooperating with peers to maintain harmony. Basically, the idea behind this theory is that every member of society has a specific function to play in order to maintain a certain level of stability (Andersen \& Taylor, 2000; Neuback \& Glasberg, 2005; Schaefer, 2009). However, based on the rational choice theory, sometimes competition or other forms of interaction occur between students, due to their own choices or preferences. The main idea for rational choice theory is that every individual will choose to behave based on behaviour that benefits them most (Ritzer, 2003). 
Different ethnic groups hold different beliefs, values and norms, which influence their behaviors, actions, thinking and interactions with their surroundings (Najeemah, 2008). In a school which has multi-ethnic students, some would find it difficult to maintain harmonious relations because of the differences that they have. Hence, this research is carried out to identify the patterns of social interaction among Form 4 students in a national secondary school. Although there were earlier researches on student interactions, a research using a different approach, sampling method and location of research would yield different findings. Additionally, various policies and programs have been formulated by the Malaysian government since Independence Day until now, with the intention of improving interactions among ethnic groups. Therefore, it is necessary for us to explore and identify the patterns of social interactions that exist among students at this moment, as a consequence of the policies in place presently.

\section{Method}

\subsection{Research Method}

A case study method has been chosen to explore the patterns of interactions among multi-ethnic students. This case study involves the gathering of data in a systematic, holistic and detailed manner by focusing the research on individuals, a group of individuals or a section of the society in an in-depth and specific manner (Merriam, 1998; McMillan \& Schumacher, 2006; Creswell, 2007).

\subsection{Participants}

The respondents for this research were chosen through a purposive sampling method. This method is used in qualitative research because it enables the researcher to choose respondents that can give detailed answers to the research questions (Merriam 1998; Creswell, 2007). A total of 2 school administrators, 7 teachers and 20 form 4 students from various ethnic backgrounds ( 9 Malays, 6 Chinese, 4 Indians and an Orang Asli) were chosen as respondents. As an ethical precaution, the researcher had circulated consent forms. This form is very important, as it informed the prospective respondents about the research and also obtained their consent (Lambert, 2012).

\subsection{Data Collection}

Three methods were used to collect data: interviews, observation and document analysis. Individual interviews involved the teachers and administrators, while group interviews were conducted with the students. The researcher had chosen semi-structured questions and all interviews had adhered to interview protocols. In general, the semi-structured questions were pre-formulated before the interview but the answers to these questions were open-ended and could be expanded according to the discretion of the interviewer and interviewee (Hays \& Singh, 2012).

Observation is the main form of collecting data in the field of qualitative research (Bailey, 2007; Hays \& Singh, 2012). So, in order to substantiate this research, the observation was carried out in the class, canteen, during school activities, assemblies and in areas surrounding the school. Document analysis was also done to support the research data obtained via the interviews and observations. Among the documents analyzed were the school organization manual, school policies, reports on school activities/ co-curriculum and the school magazines. The use of these three methods of data collection together is called triangulation. Triangulation gives a clearer picture of the aspects being researched and substantiates the research (Bogdan, 1998; Rossman, 2003; Lambert, 2012).

\subsection{Data Analysis}

The data obtained were analyzed using the qualitative approach, which involved the process of preparing, organizing and finally the coding process of the data collected (Creswell, 2007). To increase the validity of this research, the researcher used the triangulation approach and member checking.

\section{Findings}

The data analysis has shown that there are five patterns of social interaction as listed below.

\subsection{Cooperation}

The cooperation pattern of interaction has many mutual benefits. Cooperation among students of different ethnic groups pertain to the aspects of academics (FG1, para 381).

Cooperation occurs in school activities (e.g. drama competitions, flag decoration).

P2: ...during a Merdeka celebration, we tried to involve all the ethnicities...in a group. During the celebrations, we held many activities and programs such as a flag contest, drawing contest and these activities were carried out in groups which had a mixture of different ethnicities. 


\subsection{Exchanges}

Social interactions in the form of exchanges are also seen among students, in academic and school activities. Malay students would inquire and learn how to solve problems (on the subject of economics) from Chinese students and vice-versa. When the smarter student helps his fellow student, this benefits the weaker student (P2: Mariam, para 52).

According to a teacher from the Tamil Language Association, during the Cultural Night activity, students were helping one another during the dance activity. The Malay students voluntarily lent their costumes to the Indian students. Without the help from the Malay students, the dancing activity would not have been a success. (G5: Rekha, para 158-160).

\subsection{Competition}

Competition also occurs among students in both academic and school activities. From the academic aspect, students compete over assignments, exams and during learning sessions such as during experiment session. Competition over academic aspects is unavoidable. But it often does not cause any misunderstandings. (G1: Salmah, para 40-46).

Meanwhile in school activities, competition was observed, for example during a calligraphic competition by the Chinese Language Association, quizzes, etc (P1: Kalsom, para 104).

\subsection{Non-verbal Communication}

Observations in a formal condition (laboratory or classroom) and informal condition (sports day or canteen), non-verbal communication such as tapping shoulders, standing closely to each other and smiling can be seen among students regardless of their ethnicity. The following is an excerpt from the field note.

Our respondents (Azmir and Jeevan) were in the same group which also consisted of two other Malay students. We saw Jeevan walking to the other group and touching Heng's (Chinese) shoulder. They stood very close to each other.

(Class observation (4P1): June 24, 2013, Monday)

Our respondents, Gethana (Indian), Yan Tin (Orang Asli), and Nisha (Malay) sat together near the school field. We saw them sit very closely, chatting among each other and they laugh happily. Sometimes, we saw Yan Tin, touching and poking Nisha and Gethana on the shoulder. They also leaned on each other's shoulders.

(Observation during Sports Day: 22 June 22, 2013, Saturday)

\subsection{Conflict}

Conflicts do happen among students. Conflicts among similar ethnic groups mostly involved the Malays and Indians. Conflicts within similar ethnic groups were often caused by relationship problems, friendship problems and inter-relative squabbles (P1: Kalsom, para 80).

Meanwhile, conflicts also occurred among different ethnic groups. Usually they began with teasing or jeering and sometimes it would end up with fighting. However, the reasons for quarrels were not due to racism and the numbers of cases are diminishing. (P2: Madam Mariam, para 102-104).

As stated earlier, conflicts occurred but were not serious and the motives were not racial issues. Besides that, the students do not have negative attitudes such as racism, prejudices, ethnocentrism, threats, hatred and isolation of friends. (FG1: para 389-391).

Although conflicts do occur, there are still good friends from different ethnic groups and they can accept the cultural differences among them. (FG1: para 3-6) and (FG2: para 354-358).

In addition, the students willingly learn these cultural differences by attending activities that have been held by Tamil Language Association. These are good signs and their interactions are still at an appreciable level. (G5: Rekha, para 30-32).

\section{Discussion and Summary Review}

There are several forms of social interactions among the society members, such as cooperation, exchanges, competition, non-verbal communication and conflict (Tischler, 2011). Various forms of social interactions exist, because the roles played by an individual in one situation differ from another (Noran Fauzan Yaakub, 1987). Since each individual, for example a student, has more than one role to play, there are various forms of social interactions and reasons for these interactions. 
Cooperation is one form of interaction that is based on the premise that, all individuals involved work together to achieve common interests (Foster, 2001; Tischler, 2011). In the context of this research, students were found to cooperate among each other to finish group assignments (in academic aspects) and did their best in the drama and drawing competitions (alternative school activities) in order to achieve a common interest, which is to produce the best possible work and win. Although the Orang Asli were a minority group in the school, they could still work together with their friends from other ethnic groups. Findings of the study show that, through group assignments cooperation among students was instilled. Previous research had similar findings through group assignments, the value of cooperation, acceptance of others and good relationships could be developed (Bliss, 1989; Slavin \& Cooper, 1999; Johnson, Johnson \& Taylor, 2001; Toumasis, 2004; Gillies, 2006; Gonçalves, 2011; Ramani, 2012). Furthermore, through cooperation, individuals will feel inter-dependent among each other (Smith, 1996; Sahlberg, 2010; Sharan, 2010) and the acceptance toward others is instilled (Foster, 2001; Sharan, 2010). Overall, cooperation among students from different ethnic groups can be seen in a school with a diversified student population, such as a national secondary school in Malaysia.

Exchange interactions occur when an individual hopes for a reward. Rewards are not only in the form of materials (money) but also verbal appreciation such as praises and word of thanks from the party that received the help (Tischler, 2011). This research found that exchange interactions do occur in the academic aspect, whereby a bright student would help a weaker student regardless of their ethnic background. The benefit obtained at the end of the interaction is that the weaker student would eventually understand his lessons. Other researches had similar findings whereby inter-ethnic relations delivered benefits in the learning aspect, when the students provide detailed explanations and assistance with school work (Webb \& Mastergeorge, 2003; Webb, Farivar \& Mastergeorge, 2002; Feng Li, 1997). Exchange interactions can also be seen during co-curriculum activities. It gave benefits to the students involved and those who provided the help would receive appreciation in the form of a thank-you. In general, students tend to help those who are closer to them. Thus, the closer they are, the more they will adopt this pattern of interaction.

The next form of social interaction is competition. Competition can bring about a positive or negative effect. For example, findings from the study by Literte (2011) and Schneider et al. (2005) had found that competition among students occurred in various situations and that it caused tension in their relationships. Apart from that, according to Black (2005) competition in the learning aspect had sometimes caused dissatisfaction among students. However, the findings in this research shows competition in the academic aspects had brought about a positive effect, whereby students tended to strive and compete to achieve the best and it did not cause any tension in their relationships. There are several researches that supported these findings which showed competition would increase a student's motivation to succeed or produce the best (Shui-fong et al., 2004; Kailas, 2001; Bolocofsky, 2001).

Competition is a form of interaction, where each individual would compete to obtain a reward or some limited resource (Charlesworth, 1996; Schneider et al., 2005; Tischler, 2011) and it is based on one rule mutually agreed upon (Tischler, 2011). In the context of this research, competition was seen during the quiz, calligraphy writing competition, sports events and so on. Students compete among themselves to win prizes and all the students who participated understood the rules of the competition. The student who produced the best results was the winner. Furthermore, when there was a reward or prize, it was found to increase extrinsic motivation for the individual to compete (Abuhamdeh \& Csikszentmihalyi, 2009). Overall, competition brought about a positive impact, where it caused an increase in student's achievement and also their motivation to compete continuously.

Conflict is a common phenomenon in life because there is contact among individual and when differences in values, belifs, and attitude regarding issues arise (Laursen, 1995; Aboud \& Miller, 2007). Therefore, it is not surprising that conflict occurred among the students during this research. The motives for quarrels among similar ethnic groups (Indians and Malays) were often due to individual standing-up for lovers, friends or relatives. Meanwhile, conflict between different ethnic groups was often caused by dissatisfaction over class-keeping chores and teasing, which ended with quarrels. Although conflicts still occur, the numbers of cases are declining and the causes are not race related. Past research had shown that various causes were responsible for conflicts among students. A study done by Laursen (1995) had found that conflicts among fellow friends frequently occurred because of differences in ideas, views, teasing, criticism and annoying behaviors. Meanwhile, Nur Azuki, Nik Yusri \& Wan Sopian (2012) had found that different spoken languages had also caused conflicts among students. Findings by Najeemah (2006) showed that quarrels that involved different ethnicities or similar ethnicities are due to various reasons and sometimes students being threatened in schools by other ethnic groups.

Negative attitudes such as bias, racism and stereotypes are often the precursor towards conflict. Findings of this research had also shown that, there was stereotyping among students, especially towards Malays and Indians. 
Stereotyping is an assumption of what people are like, whether true or false, and it can affect social interaction (Henslin, 2012). This is because whatever perception we hold towards others depicts our reaction toward them. So, it is obvious that stereotyping would disrupt racial relations and interactions (Mohd, Dayu \& Budi, 2011) and stereotyping can be reduced by socializing with friends from different ethnic backgrounds (Mcglothin \& Killen, 2010; Ngai \& Koehn, 2010). The relationship between a stereotyping attitude and interaction can be seen in numerous researches whereby the stereotyping attitude had impeded students' interaction (Finchilescu, 2010; Chongruksa \& Prinyapol, 2011; Literte, 2011).

Although this research has shown the presence of stereotyping, there are no negative attitudes such as bias, ethnocentrism, threats, racism and isolation of friends. This indicates that student relations are still maintained and can be improved upon. If the students had extremely negative attitudes, it would contribute to uncontrolled conflicts. If we examine some of the researches done abroad, it is obvious that negative attitude impedes good interactions and cause conflicts among students (Smith, 2009; McGlothlin \& Killen, 2006; Brockett, Village \& Francis, 2010). Furthermore, the conflict among students in this research is not something that is serious and does not hold extreme underlying issues such as racism, thus, it differs from conflicts abroad, which are caused by elements of racism in some studies (Thomas, 2003; Riley \& Ettlinger, 2011; Reason \& Evans, 2007). Racism is a negative attitude (Buchanan, 2011; Rosvall \& Öhrn, 2014) and according to Mc Neely \& Badami (1984) when interactions among students of different ethnic backgrounds decrease, racism will occur.

Besides this, findings from this research have shown that students still possess attitudes that accept and try to learn other cultures. If this kind of attitudes still exists, this indicates that student relationships are still good. Furthermore, a continuous positive interaction is extremely necessary to increase the sense of acceptance among different ethnic groups (Aboud, Mendelson \& Purdy, 2003; Yip, Seaton \& Sellers, 2010; Ngai \& Koehn, 2010; Ljujic, 2011; Sánchez-Martí \& Ramírez-Iñiguez, 2012). Findings also showed that students still have best friends from other ethnic backgrounds. This implies that the acceptance attitude toward other ethnic groups still exists among students (Mcglothlin \& Killen, 2010). However, the findings of this study differ from some studies (Hallinan \& Teixeira, 1987; Aboud, Mendelson \& Purdy, 2003; McCill, Way \& Hughes, 2012) whereby students tend to have close friends within their own ethnic group.

If a student were to be placed in a multi-ethnic surrounding, extremely negative attitudes that contribute to conflicts would be reduced and healthy relations could be built (Pagani, 2014). This is made possible; as a surrounding that contains a multi-ethnic composition would render exposure and greater opportunities to build relationships among the different ethnic groups (Howes \& Wu, 1990; Lee, Howes \& Chamberlain, 2007; Ramiah, et al, 2013; Keddie, 2014). In the context of this study, the students were in multi-ethnic secondary schools and this will help to nurture positive interaction among them. Some previous research findings have shown the significance of a multi-ethnic learning environment that can help to form positive attitudes and increase the socialization of students (Munniksma \& Juvonen, 2012; Chang, Astin \& Kim, 2004; Warikoo, 2010; Cowan, 2005; Tropp \& Bianchi, 2006).

Non-verbal communication is also classified as a form of social interaction (Tischler, 2011). According to Henslin (2012), personal space, eye contact, smiles and body language are a few of the aspects of social interactions. The finding of this study revealed that there were behaviors such as tapping shoulders, poking friends, smiling, laughing, standing or sitting closely among friends of different ethnic backgrounds. These baehaviours concurs with Benzer (2012), Ibrahim (2012) that generally, non-verbal communication involves the process of delivering a message through facial expressionss, eye contact, body movements and certain gestures. Whereas, verbal communication occurs in the form of words and sentences (Ibrahim, 2012). Therefore, it is obvious that interaction is not only limited to speech or verbal mode but also involves action or behavior, which is another form of interaction among individuals. Benzer (2012) stated that when an individual uses non-verbal communication, it is a form of communication, which resembles the internal feelings of a person. Furthermore, non-verbal communication portrays an important picture about the closeness of one individual to another, such as the standing distance between two individuals, also known as the social distance (Karp \& Joel, 1986). In the context of this research, the inter-ethnic relations among students were good because there was still non-verbal action such as that stated earlier. It can be summarized that communication is one way of delivering ideas between two or more individuals either in a verbal or non-verbal form (Ibrahim, 2012).

\section{Conclusion}

The purpose of this study was to provide additional understanding regarding social interactions among multi-ethnic students in one of the secondary schools in Malaysia. Overall, the patterns of social interactions that occurred among the students were cooperation, exchanges, competitions, conflicts and non-verbal 
communication such as tapping shoulders, poking friends, smiling, laughing, standing or sitting closely among friends of different ethnic backgrounds. These various patterns of interactions were due to the different roles that the student had to play in the different situations imposed on the student in the school. In general, conflicts do occur in this school, but the underlying reasons were not due to racial sentiments or extreme negative attitudes such as that are found in certain countries abroad.

But the most important thing to note is that, all students regardless of their ethnicities are able to cooperate amongst themselves. This scenario has been documented in other researches done by Johnson, Johnson \& Taylor (2001); Chang, Astin \& Kim (2004); Toumasis, (2004); Gillies (2006); Ramlee et al. (2009); Ezhar (2009); Zaharah et al. (2010) and Ramani (2012). Surely, there is stereotyping among the students but with the absence of negative attitudes such as racism, prejudice, ethnocentrism, threats or isolation of friends based on ethnic origin. If the students possess extreme negative attitudes, it would contribute towards severe conflicts. The findings of this research are in congruence with the theory of functionalism, whereby students played their role competing in a healthy manner in the academic and school activity aspects. They were also able to play their role effectively, to cooperate in school activities regardless of their ethnic background. However, sometimes they failed to fulfill their role as a student and were involved in conflicts that had negative attitudes such as stereotyping, as discussed earlier.

The findings also showed that students choose to interact with friends from different ethnic backgrounds due to the benefits to be gained by such actions. Thus, the findings of this study are consistent with the idea of rational choice theory, whereby every action or behavior is the individual's choice and it is underlined by the potential benefits awaiting the individual. For example, all students participated in exchange interactions because of the benefits they would gain.

When the students in this study showed interest in learning other cultures and had close friendships with people from different ethnicities, this clearly showed that student relationships are still favorable. So, the relationships and interactions among students can be improved with an appropriate approach by all parties. For example, teachers as educators should emphasize the importance of positive interaction among different ethnic groups (McKenzie \& Purdy, 2010; Radstake \& Leeman, 2010), try to instill acceptance of diversity during teaching sessions (Dimitriadou, Tamtelen \& Tsakou, 2011). Apart from that, school should not only organize cultural celebrations, but have to vary their approaches to strengthen social interaction in preparing students for multicultural citizenship. In summary, it is very important to create an awareness of the diversity of ethnicities from early life, especially during school age.

\section{References}

Aboud, F. E., \& Miller, L. (2007). Promoting peer intervention in name-calling. South African Journal of Psychology, 37(4), 803-819. http://dx.doi.org/10.1177/008124630703700409

Aboud, F. E., Mendelson, M. J., \& Purdy, K. T. (2003). Cross-race peer relations and friendship quality. International Journal of Behavioral Development, 27(2), 165-173. http://dx.doi.org/10.1080/01650250244 000164

Abuhamdeh, S., \& Csikszentmihalyi, M. (2009). Intrinsic and Extrinsic Motivational Orientations in the Competitive Context: An Examination of Person-Situation Interactions. Journal of Personality, 77(5), 1615-1635. http://dx.doi.org/10.1111/j.1467-6494.2009.00594.x

Ambalakan, K. (2008). Identiti India di Malaysia. Minden, Penang: USM.

Amir, H. D. (2006). Penteorian sosiologi dan pendidikan. Tg Malim: Quantum Books.

Andersen, M. L., \& Taylor, H. F. (2000). Sociology: Understanding a diverse society. Belmont, CA: Wadsworth Thompson Learning.

Azmah, A. M. (2001). Sejarah sosial masyarakat Malaysia. Kuala Lumpur: Utusan Publications \& Distributors Sdn. Bhd.

Bailey, C. (2007). A guide to qualitative field research. California, USA: Sage Publication.

Benzer, A. (2012). Teachers' opinions about the use of body language. Education Spring, 132(3), 467-473.

Berns, J. et al. (2005). Education policy in multi-ethnic societies: A review of national policies that promote coexistence and sosial inclusion. Retrieved October 20, 2012, from http://www.brandeis.edu/ethics/pdfs/ publications/ EducationPolicy.pdf

Black, S. (2005). The trouble with classroom competition is that it brands every kid a loser except one: And the 
winner is. American School Board Journal, 192(7), 33-35.

Bliss, T. (1989). The use of groupwork in high school social studies. Theory and Research in Social Education Fall, 17(4), 304-315. http://dx.doi.org/10.1080/00933104.1989.10505596

Bogdgan, R. C., \& Biklen, S. K. (1998). Qualitative research for education: An introduction to theory and methods. Bostan: Ally \& Bacon.

Bolocofsky, D. N. (2001). Motivational Effects of classroom competition as a function of field dependence. The Journal of Educational Research, 73(4), 213-217. http://dx.doi.org/10.1080/00220671.1980.10885238

Brockett, A., Village, A., \& Francis, L. J. (2010). Assessing out group prejudice among secondary school pupils in Northern England: Introducing the out group prejudice index. Research in Education, 83(1), 67-77.

Buchanan, J. (2011). Racist in the woodpile? Prejudice and education. Intercultural Education, 22(3), 179-188. http://dx.doi.org/10.1080/14675986.2011.592031

Chang, M. J., Astin, A. W., \& Kim, D. (2004). Cross-racial interaction among undergraduates: Some consequences, causes, and patterns. Research in Higher Education, 45(5), 529-553. http://dx.doi.org/10. 1023/B:RIHE.0000032327.45961.33

Charlesworth, W. R. (1996). Co-operation and competition: Contributions to an evolutionary and developmental model. International Journal of Behavioral Development, 19(1), 25-38. http://dx.doi.org/10.1177/0165025 49601900103

Chongruksa, D., \& Prinyapol, P. (2011). Efficacy of group counseling on multicultural awareness and respect among Thai Buddhist and Thai Muslim students. Counseling Psychology Quarterly, 24(3), 181-193. http://dx.doi.org/10.1080/09515070.2011.615135

Cowan, G. (2005). Interracial interactions at racially diverse university campuses. The Journal of Social Psychology, 145(1), 49-63. http://dx.doi.org/10.3200/SOCP.145.1.49-64

Creswell, J. W. (2007). Qualitative inquiry \& research design: Choosing among five approaches. Thousand Oak, California: Sage Publications.

Dimitriadou, C., Tamtelen, E., \& Tsakou, E. (2011). Multimodal texts as instructional tools for intercultural education: A case study. Intercultural Education, 22(2), 223-228. http://dx.doi.org/10.1080/14675986.2011. 567080

Ezhar, T. (2009). Contribution of interethnic contact on interethnic attitudes of Malay and Chinese-Malaysian university students in Malaysia. European Journal of Social Sciences, 8(1), 51- 61.

Feng, L. (1997). Helping behaviors and the perception of helping intentions among Chinese students. The Journals of Social Psychology, 137(4), 496-501. http://dx.doi.org/10.1080/00224549709595466

Finchilescu, G. (2010).Intergroup anxiety in interracial interaction: The role of prejudice and metastereotypes. Journal of Social Issues, 66(2), 334-351. http://dx.doi.org/10.1111/j.1540-4560.2010.01648.x

Foster, W. K. (2001). Cooperation in the game and sport structure of children: One dimension of psychological development. Education, 105(2), 201-205.

Gillies, R. M. (2006). Teachers' and students' verbal behaviours during cooperative and small-group learning. British Journal of Educational Psychology, 76, 271-287. http://dx.doi.org/10.1348/000709905X52337

Gomes, M. P., \& Holmberg, J. B. (2010). Reflections on teacher education for diversity. Intercultural Education, 21(5), 411-413. http://dx.doi.org/10.1080/14675986.2010.521374

Hallinan, M. T., \& Teixeira, R. A. (1987). Opportunities and constraints: Black-white differences in the formation of interracial friendships. Child Development, 58(5), 1358-1371.

Haque, M. S. (2003). The role of the state in managing ethnic tensions in Malaysia: A critical discourse. American Behavioral Scientist, 47(3), 240-266. http://dx.doi.org/10.1177/0002764203256186

Haris, M. J. (1990). Etnik, politik dan pentadbiran. Kuala Lumpur: Dewan Bahasa dan Pustaka.

Hays, D. G., \& Singh, A. A. (2012). Qualitative inquiry: In clinical and educational settings. New York: Guilford Press.

Hazri, J. (2010). Historical overview of Malaysia's experience in enhancing equity and quality of education: Focusing on management and mediation of multiethnic issues. Africa-Asia Experience Sharing Seminar: Efforts towards Improving the Quality of Education. Accra, Ghana. 19th - 21st January 2010. Retrieved 
January 20, 2015, from http://aadcice.hiroshima-u.ac.jp/e/reseach/paper_no7-1.pdf

Henslin, J. M. (2012). Sociology: A down to earth approach (11th ed.). Upper Saddle: Pearson Inc.

Howes, C., \& Wu, F. (1990). Peer interactions and friendships in an ethnically diverse school setting. Child Development, 61(2), 537-541. http://dx.doi.org/10.1111/j.1467-8624.1990.tb02798.x

Hussin, S. (2004). Pendidikan di Malaysia: Sejarah, sistem dan falsafah. Kuala Lumpur: Dewan Bahasa dan Pustaka.

Ibrahim, M. A. S. (2012). A semiotic-based approach as an effective tool for teaching verbal and non-verbal aspects of language. Journal of Language Teaching and Research, 3(6), 1150-1156. http://dx.doi.org/10. 4304/jltr.3.6.1150-1156

Ishak, S. (2009). Malaysia 1945-2000. Kuala Lumpur: Utusan Publications \& Distributors Sdn. Bhd.

Ismail, S., \& Hussin, A. (2009). Pengajian sosial 2. Shah Alam: Karisma Publication Sdn. Bhd.

Jayum, J. (2003). Malaysian politics and goverments. Shah Alam: Karisma Publications Sdn Bhd.

Johnson, D. W., Johnson, R. T., \& Taylor, B. (2010). Impact of cooperative and individualistic learning on high ability students' achievement, self-esteem and social acceptance. The Journal of Social Psychology, 133(6), 839-844. http://dx.doi.org/10.1080/00224545.1993.9713946

Kailas, N. T. (2001). Competition and instrinsic motivation. The Journal of Social Psychology, 132(6), 709-715. http://dx.doi.org/10.1080/00224545.1992.9712101

Keddie, A. (2014). The politics of Britishness: Multiculturalism, schooling and social cohesion. British Educational Research Journal, 40(3), 539-554. http://dx.doi.org/10.1002/berj.3101

Lai, F. Y., \& Md Sidin, A. I. (2012). Framing interethnic conflict in Malaysia: A comparative analysis of newspaper coverage on the Hindu Rights Action Force (Hindraf). International Journal of Communication, 6, 166-189. http://dx.doi.org/10.1080/17544750.2015.1096802

Lambert, M. (2012). A beginner's guide to doing your education research project. Thousand Oak, CA: Sage Publications.

Laursen, B. (1995). Conflict and social interaction in adolescent relationships. Journal of Research on Adolescence, 5(1), 55-70.

Lee, L., Howes, C., \& Chamberlain. (2007). Ethnic Heterogeneity of Social Networks and Cross-Ethnic Friendships of Elementary School Boys and Girls. Merrill-Palmer Quarterly, 53(3), 325-346. http://dx.doi.org/10.1353/mpq.2007.0016

Literte, P. E. (2011). Competition, conflict, and coalitions: Black- Latino relations within institutions of higher education. The Journal of Negro Education, 80(4), 477-490.

Ljujic, V. (2011). Feel threatened being prejudiced: The role of past experience and proximal threat in shaping adolescents' Romaphobia. Intercultural Education, 22(6), 521-527. http://dx.doi.org/10.1080/14675986. 2011.644953

Mc Neely, R. L., \& Badami, M. K. (1984). Interracial communication in school work. Social Work, 29(1), 22-26. http://dx.doi.org/10.1093/sw/29.1.22

McGill, R. K., Way, N., \& Hughes, D. (2012). Intra and interracial best friendships during middle school: Links to social and emotional well-being. Journal of Research on Adolescence, 22(4), 722-738. http://dx.doi.org/10.1111/j.1532-7795.2012.00826.x

McGlothlin, H., \& Killen, M. (2006). Intergroup attitudes of European American children attending ethnically homogeneous schools. Child Development, 77(5), 1375-1386. http://dx.doi.org/10.1111/j.1467-8624.2006. 00941.x

McGlothlin, H., \& Killen, M. (2010). How social experience is related to children's intergroup attitudes. European Journal of Social Psychology, 40(4), 625-634. http://dx.doi.org/10.1002/ejsp.733

McKenzie, L. R., \& Purdy, N. (2010). The impact of diversity visits for student teachers in Northern Ireland. Intercultural Education, 21(5), 415-427. http://dx.doi.org/10.1080/14675986.2010.521376

McMillan, J. H., \& Schummacher, S. (2006). Research in education: Evidence based inquiry. Boston: Allyn \& Bacon.

Merriam, S. B. (1998). Qualitative research and case study: Applications in education. New York: Jossey Bass. 
Miller, H. (2007). Malaysian heritage: The story of Malaysian. Kuala Lumpur: Synergy Media.

Mior Khairul Azrin, M. J. (2011). Sosiohumanika, 4(1), 33-48.

Mohd, S. E., Dayu, S., \& Budi, A. M. T. (2011). Hubungan etnik: Kelangsungan pembinaan negara bangsa. Selangor: Penerbitan Multimedia.

Mohd. Amar, I., Hazri, J., \& Najeemah, M. Y. (2013). Prejudis dan stereotaip dalam kalangan murid pelbagai etnik di Sekolah Menengah Kebangsaan Malaysia. Proceeding of the Global Summit on Education 2013, on 11-12 March 2013, Kuala Lumpur.

Munniksma, A., \& Juvonen, J. (2012). Cross-ethnic friendships and sense of social-emotional safety in a multiethnic middle school: An Exploratory Study. Merrill-Palmer Quarterly, 58(4), 489-506. http://dx.doi.org/10.1353/mpq.2012.0023

Najeemah, M. Y. (2006). Patterns of social interaction between different ethnic groups in Malaysian Secondary Schools. Jurnal Pendidik dan Pendidikan, 21, 149-164.

Najeemah, M. Y. (2008). Multicultural Education: Managing diversity in Malaysian schools. Malaysian Education Deans' Council Journal, 2, 1-8.

Neuback, K. J., \& Glasberg. D. S. (2005). Sociology: Diversity, conflict and change. New York: Mc Graw Hill.

Ngai, P. B., \& Koehn, P. H. (2010). Indigenous studies and intercultural education: The impact of a place-based primary-school program. Intercultural Education, 21(6), 597-606. http://dx.doi.org/10.1080/14675986.2010. 533039

Nikitina, L., \& Furuoka, F. (2013). "Dragon, Kung Fu And Jackie Chan...": Stereotypes about China held by Malaysian students. TRAMES, 17(2), 175-195. http://dx.doi.org/10.3176/tr.2013.2.05

Noran, F. Y. (1987). Pengantar sosiologi. Petaling Jaya: Penerbit Fajar Bakti Sdn Bhd.

Nur Azuki, Y., Nik, Y. M., \& Wan, S. S. (2012). Faktor utama konflik etnik dan kemampuan Gagasan 1 Malaysia menurut perspektif mahasiswa. Paper presented in Regional Conference on Values and Humanities (RECOVH) 2012, 02 - 03 December 2012, Universiti Malaysia Kelantan. Retrieved January 13, 2014, from http://umkeprints.umk.edu.my/1071/1/Paper\%201.pdf

O'Nions, H. (2010). Different and unequal: the educational segregation of Roma pupils in Europe. Intercultural Education, 21(1), 1-13. http://dx.doi.org/110.1080/14675980903491833

Onwubiko, E. C. (2012). Unifying role of Malay language in a multilingual nation: A case of Malaysia. US-China Foreign Language, 10(7), 1349-1354.

Özgen, N., \& Köşker, N. (2015). Multiculturality Attitude Scale: A Sample from Turkey International. Online Journal of Educational Sciences, 7(2), 121-129. http://dx.doi.org/10.15345/iojes.2015.02.009.

Pagani, C. (2014). Diversity and social cohesion. Intercultural Education, 25(4), 300-311. http://dx.doi.org/10. 1080/14675986.2014.926158

Pettigrew, T. F., Wagner, U., \& Christ, O. (2010). Population ratios and prejudice: Modelling both contact and threat effects. Journal of Ethnic and Migration Studies, 36(4), 635-650. http://dx.doi.org/10.1080/1369183 0903516034

Population and housing census of Malaysia. (2000). Putrajaya, Kuala Lumpur. Department of Statistic Malaysia.

Radstake, H., \& Leeman, Y. (2010). Guiding discussions in the class about ethnic diversity. Intercultural Education, 21(5), 429-442. http://dx.doi.org/10.1080/14675986.2010.521378

Ramani, G. B. (2012). Influence of a playful, child-directed context on preschool children's peer cooperation. Merrill-Palmer Quarterly, 58(2), 159-190. http://dx.doi.org/10.1353/mpq.2012.0011

Ramiah, A. et al. (2013). It's never too late for 'us' to meet 'them': Prior intergroup friendships moderate the impact of later intergroup friendships in educational settings. British Journal of Educational Psychology, 83, 57-75. http://dx.doi.org/10.1111/j.2044-8279.2011.02054.x

Ramlee, M. et al. (2009). Social integration among multi-ethnic students at selected Malaysian universities in Peninsular Malaysia: A survey of campus social climate. AJTLHE, 1(1), 35-44.

Reason, R. D., \& Evans, N. J. (2007). The complicated realities of whiteness: From color blind to racially cognizant. New Directions for Student Services, 120, 67-78. http://dx.doi.org/10.1002/ss.258

Riley, C., \& Ettlinger, N. (2011). Interpreting racial formation and multiculturalism in a high school: Towards a 
constructive deployment of two approaches to Critical Race Theory. Antipod, 43(4), 1250-1280. http://dx.doi.org/10.1111/j.1467-8330.2010.00825.x

Ritzer, G. (2003). Contemporary sociological theory and its classical roots: The basics. New York: McGraw Hill.

Rossman, G. B., \& Rallis, S. F. (2003). Learning in the field: An introduction to qualitative research. Thousand Oak, California: Sage Publications.

Rosvall, P., \& Öhrn, E. (2014). Teachers' silences about racist attitudes and students' desires to address these attitudes. Intercultural Education, 25(5), 337-348. http://dx.doi.org/10.1080/14675986.2014.967972

Sahlberg, P. (2010). Hope of cooperative learning: Intentional talk in Albanian secondary school classrooms. Intercultural Education, 21(3), 205-218. http://dx.doi.org/10.1080/14675981003760408

Sánchez-Martí, A., \& Ramírez-Iñiguez, A. A. (2012). Inclusive education: An examination of school relationships and student interactions. Intercultural Education, 23(6), 491-500.

Santhiram, R. R., \&Tan, Y. S. (2010). Ethnic segregation in Malaysia's education system: Enrolment choices, preferential policies and desegregation. Paedagogica Historica, 46(1), 117-131. http://dx.doi.org/10.1080/0 0309230903528496

Sarafidou, J. O., Govaris, C., \& Loumakou, M. (2013). The subtle-blatant distinction of ethnic prejudice among ethnic majority chidren. Intercultural Education, 24(3), 264-276. http://dx.doi.org/10.1080/14675986. 2013.799805

Schaefer, R. T. (2009). Sociology: A brief introduction. New York: McGraw Hill.

Schneider, B. H. et al. (2005). Cultural and gender differences in the implications of competition for early adolescent friendship. Merrill-Palmer Quarterly, 51(2), 163-191. http://dx.doi.org/10.1353/mpq.2005.0013

Shamsul, A. B. (1993). Masyarakat Malaysia dan alam sosialnya. Kuala Lumpur: Dewan Bahasa dan Pustaka.

Sharan, Y. (2010). Cooperative learning: A diversified pedagogy for diverse classrooms. Intercultural Education, 2l(3), 195-203. http://dx.doi.org/10.1080/14675981003760390

Shui-fong, L. et al. (2004). The effects of competition on achievement motivation in Chinese classrooms. British Journal of Educational Psychology, 74(2), 281-296. http://dx.doi.org/10.1348/000709904773839888

Slavin, R. E., \& Cooper, R. (1999). Improving intergroup relations: Lessons learned from cooperative learning programs. Journal of Social Issues, 55(4), 647-663. http://dx.doi.org/10.1111/0022-4537.00140

Smith, C. P. (2009). Children speak about interethnic and interracial friendships in the classroom: Lessons for Teachers. Multicultural education, 17(1), 38-47.

Smith, P. K. (1996). Strategies of co-operation: A commentary. International Journal of Behavioral Development, 19(1), 81-87.

Suhana, S., \& Jacob, I. J. (2012). Managing ethnic conflict for nation building: A comparative study between Malaysia and Nigeria. Asian Social Science, 8(7), 69-76. http://dx.doi.org/10.5539/ass.v8n7p69

Suseela, M., \& Nagappan, C. R. (2012). Education policies and practices to address cultural diversity in Malaysia: Issues and challenges. Prospects, 42(2), 147-159. http://dx.doi.org/10.1007/s11125-012-9227-9

Tan, J. P. et al. (2008). Socio-demographic characteristics of intercultural marriage: A study of a multi-ethnic community in Malaysia. European Journal of Social Sciences, 5(4), 30-44.

Thomas, R. (2003). Tackling conflict and promoting equality. Education Review, 17(1), 51-58.

Tischler, H. L. (2011). Introduction to sociology. California, USA: Wadsworth Cengage Learning.

Toumasis, C. (2004). Cooperative study teams in mathematics classrooms. International Journal of Mathemathics Education and Science Technology, 35(5) 669-679. http://dx.doi.org/10.1080/002073904200 0232529

Tropp, L. R., \& Bianchi, R. A. (2006). Valuing diversity and interest in intergroup contact. Journal of Social Issues, 62(3), 533-551. http://dx.doi.org/10.1111/j.1540-4560.2006.00472.x

Vedder, P., \& O'dowd, M. (1999). Swedish primary school pupils' inter-ethnic relationship. Scandinavian Journal of Psychology, 40, 221-228. http://dx.doi.org/10.1111/1467-9450.00120

Warikoo, N. K. (2010). Symbolic boundaries and school structure in New York and London Schools. American 
Journal of Education, 116(3), 423-451. http://dx.doi.org/10.1086/651415

Webb, N. M., \& Mastergeorge, A. (2003). Promoting effective helping behavior in peer-directed groups. International Journal of Educational Research, 39(1/2), 73-98.

Webb, N. M., Farivar, S. H., \& Mastergeorge, A. (2002). Productive helping in cooperative groups. Theory Into Practice, 41(1), 13-20. http://dx.doi.org/10.1207/s15430421tip4101_3

Yan, W. L., Timothy, W. W. Y., \& Yiu, K. C. (2011). School-based human rights education: Case studies in Hong Kong secondary schools. Intercultural Education, 22(2), 145-162. http://dx.doi.org/10.1080/14675986. 2011.567072

Yasmin, A., \& Najeemah, M. Y. (2010). Ethnic boundary among students in Malaysian primary schools and social interaction: A conceptual framework. Procedia Social and Behavioral Sciences, 7, 82-91. http://dx.doi.org/10.1016/j.sbspro.2010.10.013

Yip, T., Seaton, E. K., \& Sellers, R. M. (2010). Interracial and intra racial contact, school-level diversity, and change in racial identity status among African American adolescents. Child Development, 81(5), 1431-1444. http://dx.doi.org/10.1111/j.1467-8624.2010.01483.x

Zaharah, H. et al. (2010). Contribution of education to enhancing unity: Malaysian experience. The International Journal of Learning, 17(9), 197-208.

Zvi, B., Ayala, H., \& Nader, S. (2011). Jewish Palestinian integrated education in Israel and its potential influence on national and/or ethnic identities and intergroup relations. Journal of Ethnic and Migration Studies, 37(3), 389-405. http://dx.doi.org/10.1080/1369183X.2011.526777

\section{Copyrights}

Copyright for this article is retained by the author(s), with first publication rights granted to the journal.

This is an open-access article distributed under the terms and conditions of the Creative Commons Attribution license (http://creativecommons.org/licenses/by/3.0/). 